Michael J. Bradshaw, MD

Bret C. Mobley, MD

Jeffrey P. Zwerner, MD

Subramaniam Sriram, MBBS

Neurol Neuroimmunol Neuroinflamm

2016;3:e205; doi: 10.1212/ NXI.0000000000000205

\section{AUTOPSY-PROVEN DEMYELINATION ASSOCIATED WITH INFLIXIMAB TREATMENT OPEN}

Tumor necrosis factor- $\alpha(\mathrm{TNF}-\alpha)$ is a well-studied proinflammatory cytokine that contributes to the pathogenesis of immune and infectious diseases. TNF- $\alpha$ effects are mediated by signaling through TNF- $\alpha$ receptors, which are present ubiquitously. ${ }^{1}$ Limiting the actions of TNF- $\alpha$, either by blocking the receptor or inhibiting circulating (free) TNF- $\alpha$, is a useful treatment strategy in autoimmune disorders with prominent inflammation, such as inflammatory bowel disease and rheumatoid arthritis (RA). However, when treatment with agents that inhibit TNF- $\alpha$ function was applied to multiple sclerosis (MS), an unanticipated worsening was observed. The clinical trial of lenercept (a recombinant TNF- $\alpha$ receptor-immunoglobulin $1 \mathrm{~g}$ fusion protein that protected against experimental autoimmune encephalitis) for the treatment of relapsingremitting multiple sclerosis was stopped prematurely when the treatment arm was noted to have earlier and more frequent exacerbations. ${ }^{2}$ TNF- $\alpha$ antagonists are therefore contraindicated in patients with MS. In patients with no history of demyelinating disease, TNF- $\alpha$ antagonism has led to unmasking of demyelinating events with a clinical pattern typical of that seen in MS. ${ }^{3}$ All CNS cases of demyelinating disease to date have been based on clinical, laboratory, and radiographic findings. Herein we present a unique case of histologically confirmed demyelination following treatment with $\mathrm{TNF} \alpha$ inhibitors.

Case report. A 57-year-old man with chronic obstructive pulmonary disease and RA managed with infliximab (a monoclonal antibody against TNF- $\alpha$ ), methotrexate, and low-dose prednisone presented with 5 days of progressive encephalopathy, right facial weakness, ataxia, and rash.

The patient had started infliximab 4 months prior to presentation and had persistent hoarseness after pneumonia, which was treated empirically with clarithromycin. He then developed a nonpruritic rash that spread centrifugally and concurrently developed subacute, progressive right lower motor neuron facial nerve weakness, ataxia, and encephalopathy.

On admission, the patient was treated with broadspectrum antimicrobials including bacterial, fungal, viral, and rickettsial coverage. Chest CT demonstrated lower lobe consolidations. Brain MRI demonstrated multiple lesions suggesting demyelination in the pons, middle cerebellar peduncle, right striatum, and left parietal lobe (figure, A).

The patient had leukopenia and mildly elevated liver transaminases. CSF studies were all normal other than a mildly elevated immunoglobulin G index at 0.74; no oligoclonal bands were detected. Extensive serum and CSF infectious studies were negative, including JC virus, enterovirus, EpsteinBarr virus, cytomegalovirus, varicella-zoster virus, herpes simplex virus, HIV, fungal, mycobacterial, and rickettsial testing. A biopsy of his rash was obtained and the histologic differential diagnosis included an autoimmune connective tissue disease, erythema multiforme, viral or rickettsial illness, and methotrexate-induced toxicity.

The patient's neurologic examination and the brain MRI lesions progressed over several days, and he was treated with high-dose steroids for a presumed autoimmune demyelinating syndrome with initial improvement. However, he later worsened despite plasma exchange and broad-spectrum antimicrobials.

Blood cultures grew pan-resistant Klebsiella pneumoniae and despite optimal antimicrobial treatment, the patient developed septic shock with multiorgan dysfunction and died. Brain histopathology demonstrated an acute demyelinating process.

Discussion. The case presented herein provides pathologic proof of a demyelinating process following TNF- $\alpha$ antagonism. The demyelinated areas correlated with those identified by MRI. Gross sections from these areas showed large regions of parenchymal pallor. Histochemical and immunostaining of these regions showed dense infiltrates of macrophages $(\mathrm{CD} 68+)$ and reactive glial fibrillary acid proteinpositive astrocytes. Perivascular lymphocytic infiltration was also observed, as were small foci of necrosis, a feature that has been reported with Marburg-type 

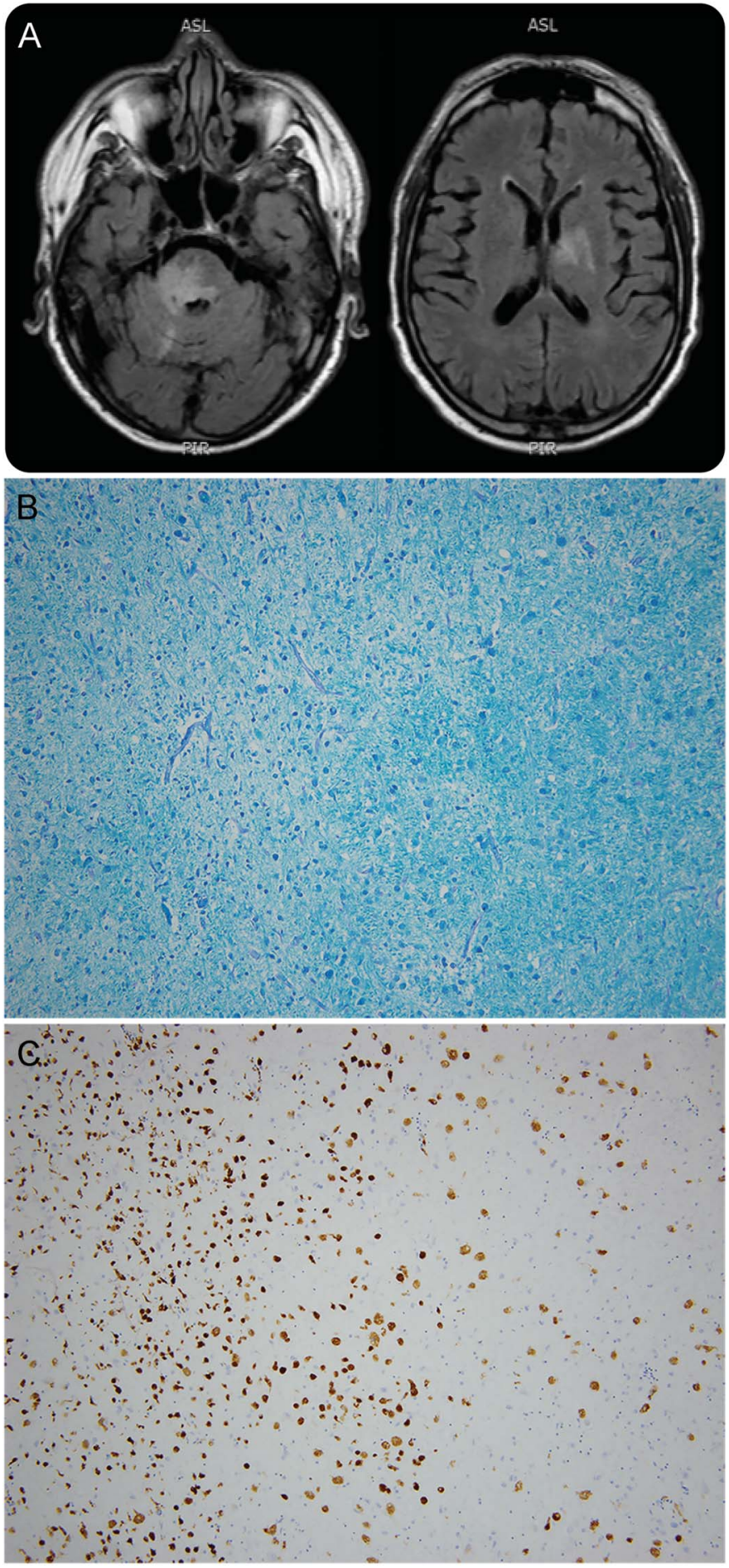

(A) Brain MRI with and without contrast. Fluid-attenuated inversion recovery sequences demonstrate T2 hyperintense lesions in the pons, right middle cerebellar, bilateral basal ganglia, left frontal and parietal lobes (not shown). The lesions in the pons and cerebellar peduncle were contrast-enhancing. $(B, C)$ Brain pathology specimens. Gross brain pathology (not shown) was remarkable for 2 regions of softening with red discoloration, the first measuring $1 \mathrm{~cm}$ in the left parietal white matter and the second measuring $2 \mathrm{~cm}$ in the pons with extension into the middle cerebellar peduncle. (B) Luxol fast blue and periodic acid-Schiff-stained section from the pons showed the interface of a hypercellular lesional area with myelin loss (left half of field) with relatively less involved white matter (right half of field). (C) CD68 immunohistochemistry revealed numerous macrophages in the involved area. CD68 specifically labels phagocytic cells of the brain, including macrophages and microglia. The larger reactive cells are intact macrophages, with foamy cytoplasm by hematoxylin \& eosin staining
MS. ${ }^{4}$ The lesions primarily involved white matter; however, the process focally extended to involve the gray matter as well. The histologic findings were specific for a demyelinating process (figure, $\mathrm{B}$ and C). Zones of demyelination were not vasculocentric, and the clinical and MRI picture was unlike that seen in acute disseminated encephalomyelitis.

Previous reports of demyelinating disease associated with TNF- $\alpha$ antagonism have included a variety of clinical manifestations of demyelination, ${ }^{5}$ as have a number of dermatologic adverse reactions. ${ }^{6}$ Most neurologic manifestations attenuate with cessation of TNF- $\alpha$ antagonism, but one study found that roughly $25 \%$ of patients developed MS despite discontinuation. ${ }^{7}$ A French national survey identified 22 patients with a central demyelination syndrome and 11 with peripheral manifestations, 2 of whom had peripheral nerve biopsies demonstrating demyelination. CSF findings in previously reported cases have been variable, ranging from normal to pleocytosis with oligoclonal bands.

Several mechanisms relating to TNF- $\alpha$ and demyelinating events have been proposed. ${ }^{3}$ For example, prolonged exposure to TNF- $\alpha$ antagonism may enhance the antigen-specific $\mathrm{T}$-cell response or alter the cytokine profile, both of which possibly favor demyelination. TNF- $\alpha$ antagonism has not been shown to induce demyelination in experimental autoimmune encephalitis ${ }^{2}$ and the mechanistic understanding of the relationship between TNF- $\alpha$ antagonism and demyelination remains unclear.

From Vanderbilt University Medical Center, Nashville, TN.

Author contributions: M.J.B.: study design, clinical review, imaging review, pathology review, manuscript preparation, editing. B.C.M.: pathology review/slide preparation, manuscript editing. J.P.Z.: pathology review/slide preparation. S.S.: clinical review, imaging review, manuscript editing.

Study funding: No targeted funding.

Disclosure: M.J.B. and B.C. Mobley report no disclosures. J.P. Zwerner served on the scientific advisory board for Actelion and has consulted for Teladoc. S.S. reports no disclosures. Go to Neurology.org/nn for full disclosure forms. The Article Processing Charge was paid by the authors.

This is an open access article distributed under the terms of the Creative Commons Attribution-NonCommercial-NoDerivatives License 4.0 (CC BY-NC-ND), which permits downloading and sharing the work provided it is properly cited. The work cannot be changed in any way or used commercially.

Received November 12, 2015. Accepted in final form December 16, 2015.

Correspondence to Dr. Bradshaw: Michael.j.bradshaw@vanderbilt.edu.

(not shown), and the smaller more intensely stained cells include smaller phagocytes and fragmented phagocytes. No nonspecific staining of neurons was present. Original magnification: $100 \times$. 
1. Brenner D, Blaser H, Mak TW. Regulation of tumour necrosis factor signalling: live or let die. Nat Rev Immunol 2015;15:362-374.

2. TNF neutralization in MS: results of a randomized, placebo-controlled multicenter study: the Lenercept Multiple Sclerosis Study Group and the University of British Columbia MS/MRI Analysis Group. Neurology 1999;53: 457-465.

3. Kaltsonoudis E, Voulgari PV, Konitsiotis S, Drosos AA. Demyelination and other neurological adverse events after anti-TNF therapy. Autoimmun Rev 2014;13:54-58.

4. Stadelmann C, Bruck W. Lessons from the neuropathology of atypical forms of multiple sclerosis. Neurol Sci 2004;25 (suppl 4):S319-S322.
5. Theibich A, Dreyer L, Magyari M, Locht H. Demyelinizing neurological disease after treatment with tumor necrosis factor alpha-inhibiting agents in a rheumatological outpatient clinic: description of six cases. Clin Rheumatol 2014;33: 719-723.

6. Hernandez MV, Sanmarti R, Canete JD, et al. Cutaneous adverse events during treatment of chronic inflammatory rheumatic conditions with tumor necrosis factor antagonists: study using the Spanish registry of adverse events of biological therapies in rheumatic diseases. Arthritis Care Res 2013;65:2024-2031.

7. Seror R, Richez C, Sordet C, et al. Pattern of demyelination occurring during anti-TNF $\alpha$ lpha therapy: a French national survey. Rheumatology 2013;52:868-874. 


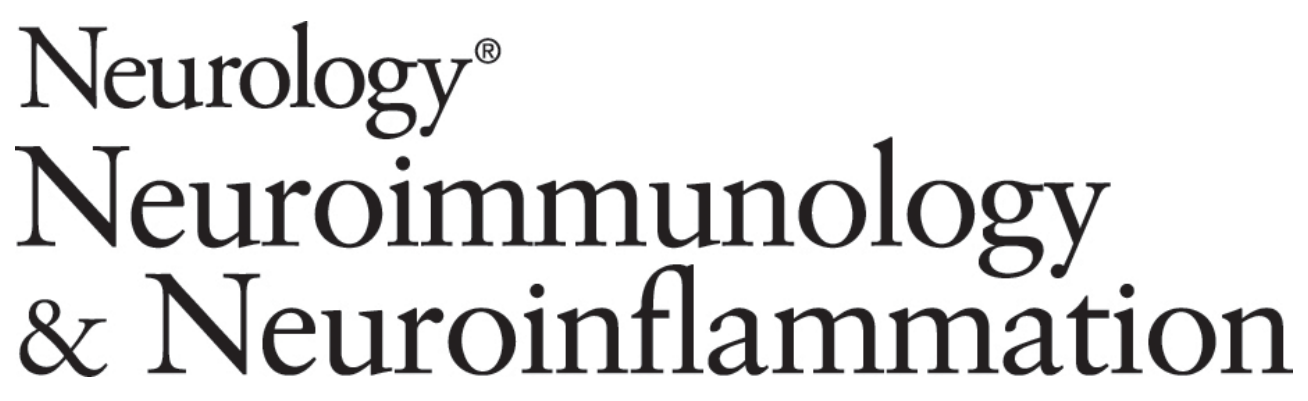

\author{
Autopsy-proven demyelination associated with infliximab treatment \\ Michael J. Bradshaw, Bret C. Mobley, Jeffrey P. Zwerner, et al. \\ Neurol Neuroimmunol Neuroinflamm 2016;3; \\ DOI 10.1212/NXI.0000000000000205
}

This information is current as of January 27, 2016

Neurol Neuroimmunol Neuroinflamm is an official journal of the American Academy of Neurology.

Published since April 2014, it is an open-access, online-only, continuous publication journal. Copyright $\odot$ 2016 American Academy of Neurology. All rights reserved. Online ISSN: 2332-7812.

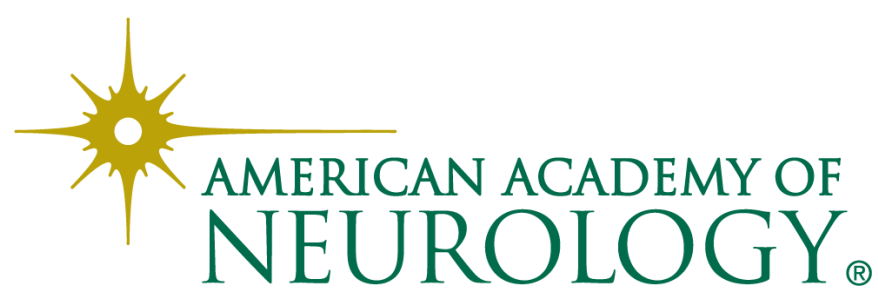




\section{Updated Information \& Services}

References

Citations

Subspecialty Collections

Permissions \& Licensing

Reprints including high resolution figures, can be found at: http://nn.neurology.org/content/3/2/e205.full.html

This article cites 7 articles, 0 of which you can access for free at: http://nn.neurology.org/content/3/2/e205.full.html\#\#ref-list-1

This article has been cited by 1 HighWire-hosted articles: http://nn.neurology.org/content/3/2/e205.full.html\#\#otherarticles

This article, along with others on similar topics, appears in the following collection(s):

Acute disseminated encephalomyelitis

http://nn.neurology.org//cgi/collection/acute_disseminated_encephalo myelitis

All Demyelinating disease (CNS)

http://nn.neurology.org//cgi/collection/all_demyelinating_disease_cns Encephalitis

http://nn.neurology.org//cgi/collection/encephalitis

Multiple sclerosis

http://nn.neurology.org//cgi/collection/multiple_sclerosis

Information about reproducing this article in parts (figures,tables) or in its entirety can be found online at:

http://nn.neurology.org/misc/about.xhtml\#permissions

Information about ordering reprints can be found online: http://nn.neurology.org/misc/addir.xhtml\#reprintsus

Neurol Neuroimmunol Neuroinflamm is an official journal of the American Academy of Neurology.

Published since April 2014, it is an open-access, online-only, continuous publication journal. Copyright $\odot$ 2016 American Academy of Neurology. All rights reserved. Online ISSN: 2332-7812.

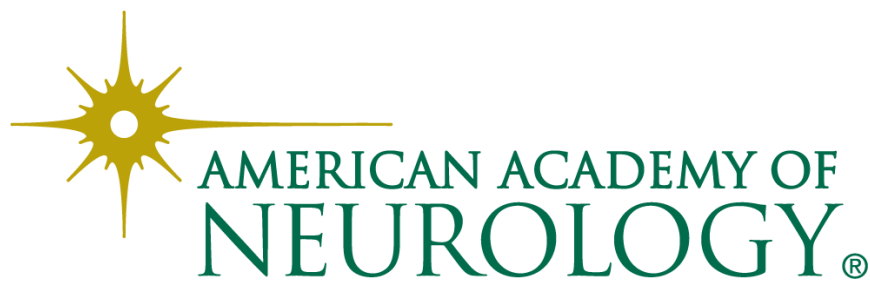

